\title{
CLASSIFICATION OF THE VIREYA GROUP OF RHODODENDRON (ERICACEAE)
}

\author{
L.A. CRAVEN ${ }^{1}$, L.A. GOETSCH${ }^{2}$, B.D. HALL ${ }^{2} \&$ G.K. BROWN ${ }^{1,3}$
}

\begin{abstract}
SUMMARY
A new classification of the Vireya group of Rhododendron, based upon their evolutionary relationships as inferred from analysis of nuclear and plastid DNA sequence data, is presented. Rhododendron sect. Vireya is not monophyletic and its species are herein placed in three sections within subg. Rhododendron, namely sect. Discovireya, sect. Pseudovireya and sect. Vireya, with two subsections recognised within sect. Vireya: subsect. Euvireya and subsect. Malayovireya. Identification keys are provided.
\end{abstract}

Key words: Ericaceae, Rhododendron, Vireya, classification, molecular systematics.

\section{INTRODUCTION}

Rhododendron L. is a large genus of Ericaceae with an estimated 600-1000 species, the number depending upon the breadth of specific variation accepted by individual workers. The genus is widely and commonly cultivated in temperate and subtemperate regions and this presumably has contributed to its intensive study by systematists as it is the subject of a voluminous literature, especially dealing with the description of new taxa. The contemporary classifications of Rhododendron are based upon the seminal publication 'Ein System der Gattung Rhododendron L.' (Sleumer 1949). Following Sleumer's publication several authors have conducted more detailed morphological studies of infrageneric groupings and, insofar as implications for disposition within the genus are concerned, these have been synthesised in the classification of Chamberlain et al. (1996). Subsequently, molecular characters obtained by sequencing nuclear and plastid DNA, have made it possible to infer evolutionary relationships within and between the relevant taxa (whether they be species, genera or families). There is little doubt that biological classification has benefited from these investigations. Infrageneric relationships of Rhododendron have been the subject of several studies based upon plastid DNA sequence data (Kurashige et al. 1998, 2001). A phylogeny derived from analysis of sequences from the nuclear RPB2-I gene (Goetsch et al. 2005) was based on species from all higher-level infrageneric groups of Rhododendron. The Goetsch et al. (2005) study is the most comprehensive molecular study of the genus published to date and its results supported the classification of Sleumer (1949) over that of Chamberlain et al. (1996). The classification of the genus proposed by Goetsch et al. (2005) is followed here.

1) Australian National Herbarium, CPBR, CSIRO Plant Industry, G.P.O. Box 1600, Canberra, ACT 2601, Australia.

2) Department of Biology, Box 1330, University of Washington, Seattle WA 98195-1330, USA.

3) School of Botany, The University of Melbourne, Victoria 3010, Australia. 


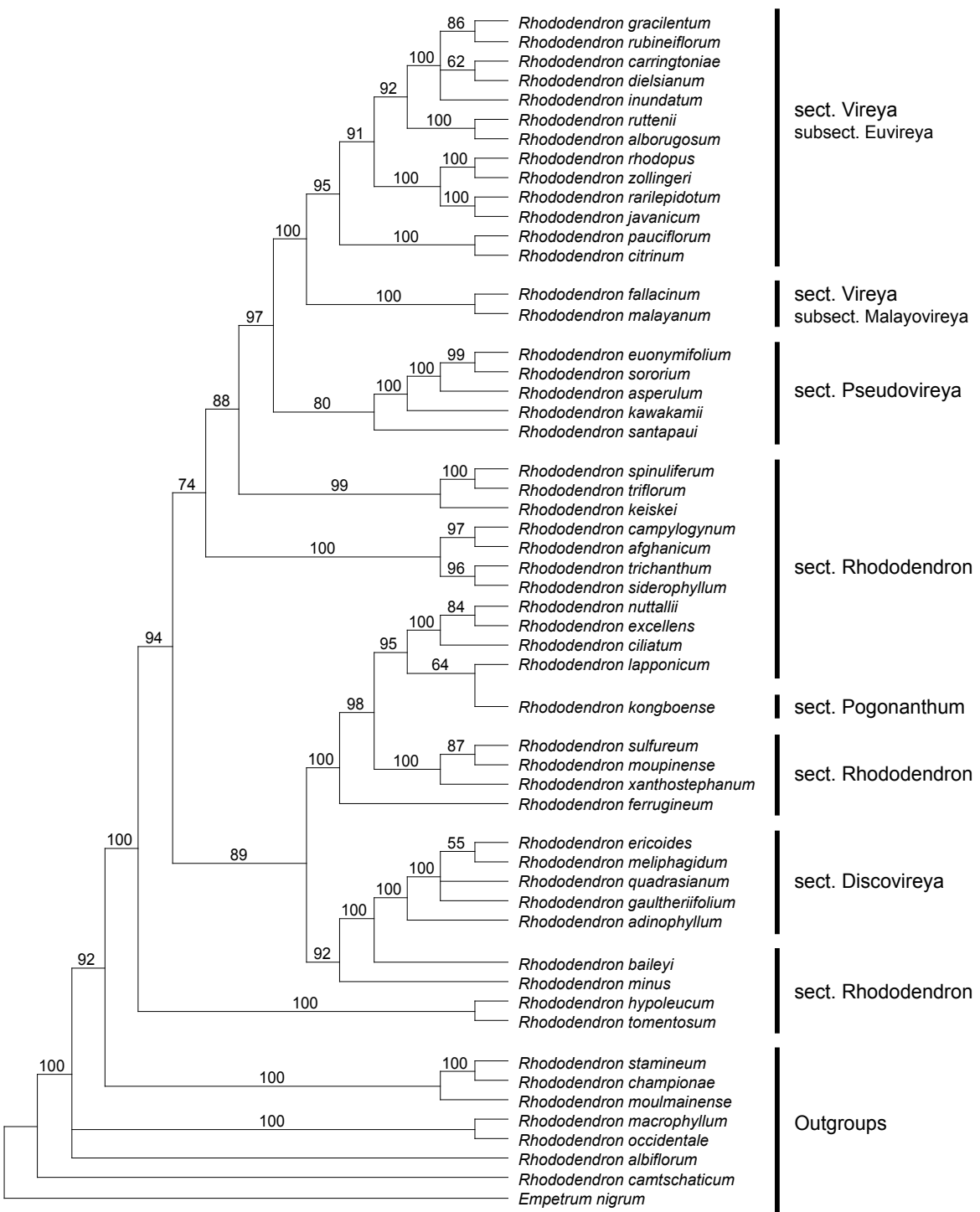

Fig. 1. Maximum parsimony strict consensus tree for Rhododendron subg. Rhododendron based upon RPB2-i sequences. All bootstrap values $>50 \%$ are shown. Based on Hall et al. (2006).

The largest section of Rhododendron is sect. Vireya (Blume) H.F.Copel., as defined by Sleumer (1966). Section Vireya contains about 300 species and is divided into seven subsections (Sleumer 1966). The Malesian representatives are divided amongst all seven subsections, while the non-Malesian species of Vireya are restricted to only three subsections: subsect. Euvireya H.F.Copel., subsect. Malayovireya Sleumer and subsect. Pseudovireya (C.B.Clarke) Sleumer. Argent (2006) published a new classification of 
Vireya sensu Sleumer that raised sect. Vireya to subgeneric rank with seven included sections. Within one of these, sect. Euvireya, five subsections were recognised. Four of Argent's sections are as circumscribed by Sleumer (1966, as subsections), two comprise species that Sleumer had allocated to subsect. Pseudovireya, and one is based on the merger of Sleumer's subsect. Euvireya and subsect. Solenovireya H.F.Copel. The classification of Argent (2006) is not congruent with that suggested by phylogenetic analyses based on DNA data. Data generated from two cpDNA intergenic spacer regions, $p s b \mathrm{~A}-t r n \mathrm{H}$ and $\operatorname{trn} \mathrm{T}-\operatorname{trn} \mathrm{L}$, indicated that subsect. Pseudovireya was paraphyletic, Malayovireya and Siphonovireya Sleumer were monophyletic, and that the remaining polyphyletic subsections, Albovireya Sleumer, Euvireya, Phaeovireya Sleumer and Solenovireya, formed a major clade (Brown et al. 2006a). Similar results were found in the phylogenetic study based on sequences of the ITS region of nuclear ribosomal DNA (Brown et al. 2006b).

Section Vireya sensu Sleumer (1966) was identified as polyphyletic based on data from the nuclear gene RPB2-i (Hall et al. 2006); this study included greater taxonomic diversity within subg. Rhododendron than the previous molecular phylogenetic studies by Brown et al. (2006a, b). Results of Hall et al. (2006) are summarised in Fig. 1 (details of voucher specimens are provided or referenced in Appendix 1). The clade of Asian mainland species of subsect. Pseudovireya was sister to a strongly supported clade of the other six subsections of section Vireya. The Malesian species of Pseudovireya were monophyletic and formed a clade with the North American R. minus Michx. and the Asian R. baileyi Balf.f. (both species of sect. Rhododendron). This clade is sister to an assemblage containing sect. Pogonanthum G.Don and representatives of most major subsections of sect. Rhododendron.

The results of Hall et al. (2006) have implications for the classification of vireyas, indicating that there are three groups of Vireya that should be recognised as separate taxa of equal rank, i.e., the Asian species of Pseudovireya, the Malesian species of Pseudovireya, and the core vireyas (the remaining six subsections sensu Sleumer). Further research using another nuclear gene (RPC1) confirms the resolution of Discovireya and the mainland Pseudovireya species into separate clades (Goetsch \& Hall unpubl.). The classification proposed by Argent (2006) is rejected because it is artificial (as acknowledged by Argent) and formal classification should always be based upon evolutionary relationships, as far as these are known. Furthermore, it results in an unbalanced classification, as molecular studies clearly show the vireya group is polyphyletic and embedded within subg. Rhododendron and therefore cannot be a sister taxon to it as depicted in Argent (2006: 4).

The classification presented below is based on the results of Hall et al. (2006) plus Goetsch \& Hall's unpublished data. Relationships within sect. Rhododendron are complex and are the subject of ongoing research, hence this section is treated below in its traditional sense following Sleumer (1949) and Chamberlain et al. (1996). The relative positions of the three vireya groups are clear. We agree with Argent's views (Argent 2006) that a practical method is required for dealing with the large number of species involved; there are nearly 300 species within sect. Vireya as it is defined here. The most satisfactory way of achieving this end is to treat the relevant subsections sensu Sleumer (1966) as informal groups, thus facilitating identification but not compromising the tenet that formal classification should be based on evolutionary 
Table 1. Comparison of the classification by Sleumer (1966) and Argent (2006) of Rhododendron sect. Vireya (sensu Sleumer 1966) with that of Craven et al. (this paper).

\begin{tabular}{lll}
\hline Sleumer 1966 & Argent 2006 & Craven et al. (this paper) \\
\hline sect. Vireya & subg. Vireya & \\
subsect. Albovireya & sect. Albovireya & sect. Vireya subsect. Euvireya \\
subsect. Euvireya & sect. Vireya (as Euvireya) & sect. Vireya subsect. Euvireya \\
subsect. Malayovireya & sect. Malayovireya & sect. Vireya subsect. Malayovireya \\
subsect. Phaeovireya & sect. Phaeovireya & sect. Vireya subsect. Euvireya \\
subsect. Pseudovireya ${ }^{1}$ & sect. Discovireya & sect. Discovireya
\end{tabular}

relationships. Unpublished data of Goetsch \& Hall show that subsect. Malayovireya is sister to the remainder of the core vireyas and within sect. Vireya we have recognised two subsections, i.e., Euvireya and Malayovireya. Molecular evidence presently does not support taxonomic recognition of the other subsections and series (sensu Sleumer 1966) of the core vireyas, other than Malayovireya. It would appear that the core vireya complex is comprised of a large group of actively evolving (including radiating and interbreeding) species, of which the speciose and morphologically ultradiverse New Guinea clade is a notable example. The classifications of Sleumer (1966) and Argent (2006) are compared in Table 1 with that presented below. To facilitate identification of specimens of subg. Rhododendron and of informal groups within subsect. Euvireya, keys are provided below the classification.

\section{RHODODENDRON}

\section{Rhododendron L.}

subg. Rhododendron

\section{sect. Rhododendron}

sect. Pogonanthum G.Don

sect. Vireya (Blume) H.F.Copel. (1929) 136, 151. - Vireya Blume (1826) 854. - subg. Vireya (Blume) C.B.Clarke (1882) 462. - Type: Rhododendron javanicum (Blume) Benn. (Vireya javanica Blume).

subsect. Euvireya H.F.Copel. (1929) 137, 159. — ser. Javanica Sleumer (1960)

176. - Type: Rhododendron javanicum (Blume) Benn. (Vireya javanica Blume).

sect. Linnaeopsis Schltr. (1917) 144. - subsect. Linnaeopsis (Schltr.) Sleumer (1949) 541. - Type: Rhododendron linnaeoides Schltr. subsect. Solenovireya H.F.Copel. (1929) 136, 158. - Type: Rhododendron jasminiflorum Hook. 
subsect. Malesia H.F.Copel.(1929) 136, 151. - Type: Rhododendron bagobonum H.F.Copel.

subsect. Phaeovireya Sleumer (1949) 539. - sect. Phaeovireya (Sleumer) Argent (2006) 21. - Type: Rhododendron beyerinckianum Koord.

subsect. Siphonovireya Sleumer (1960) 68. - sect. Siphonovireya (Sleumer)

Argent (2006) 21. - Type: Rhododendron habbemae Koord. subsect. Albovireya Sleumer (1960) 107. - sect. Albovireya (Sleumer) Argent (2006) 22. - Type: Rhododendron album Blume.

ser. Linnaeoidea Sleumer (1960) 134. - Type: Rhododendron anagalliflorum Wernham.

ser. Saxifragoidea Sleumer (1960) 141. - subsect. Saxifragoidea (Sleumer)

Argent (2006) 22. - Type: Rhododendron saxifragoides J. J.Sm.

ser. Taxifolia Sleumer (1960) 141. - Type: Rhododendron taxifolium Merr. ser. Stenophylla Sleumer (1960) 141. - Type: Rhododendron stenophyllum Hook.f.

ser. Citrina Sleumer (1960) 144. - Type: Rhododendron citrinum (Hassk.) Hassk.

ser. Buxifolia Sleumer (1960) 145. - Type: Rhododendron buxifolium Low ex Hook.f.

subsect. Malayovireya Sleumer (1958) 48. — sect. Malayovireya (Sleumer)

Argent (2006) 21. - Type: Rhododendron malayanum Jack.

sect. Pseudovireya (C.B.Clarke) Argent (2006) 19. - subg. Pseudovireya C. B.Clarke (1882) 464. - ser. Vaccinioides Hutch. (1930) 817 (here lectotypified). — subsect. Pseudovireya (C.B.Clarke) Sleumer (1949) 537. - Type: Rhododendron vaccinioides Hook.f.

sect. Discovireya (Sleumer) Argent (2006) 21. - subsect. Discovireya Sleumer (1949) 539. - Type: Rhododendron retusum (Blume) Benn. (Vireya retusa Blume).

subg. Hymenanthes K.Koch

subg. Choniastrum (Franch.) Drude

subg. Azaleastrum Planch.

subg. Therorhodion (Maxim.) Drude

Notes - 1. The name Rhododendron ser. Vaccinioides Hutch. (Hutchinson 1930: 817) has not previously been lectotypified as far as we are aware. It is here typified with $R$. vaccinioides Hook.f., the first described species of its group.

2. Argent (2006) cited Sleumer as the combining author for the name Rhododendron sect. Pseudovireya and as the author for the name Rhododendron sect Albovireya, giving as the references for these names Sleumer (1949: 537) and Sleumer (1960: 107), respectively. In his 1949 publication, Sleumer treats Pseudovireya at the rank of subsection and, in his 1960 publication, he treats Albovireya also at subsectional rank. We have seen no evidence that Sleumer believed the two taxa should be treated at the rank of section. Argent, whether or not inadvertently, has made the new 
combinations because in accordance with Art. 46.4 of the International Code of Botanical Nomenclature (Greuter et al. 2000) the names are to be attributed to him, as given in the classification above.

3. Characteristic features, noting that exceptions may sometimes occur in individual species, that serve to differentiate between the five sections of subg. Rhododendron and the two subsections of sect. Vireya are as follows:

sect. Rhododendron - Scales entire to crenulate; corolla campanulate to funnel-shaped or tubular; stamens 10, exserted, staminal filaments hairy towards the base or glabrous; capsule valves not twisting after dehiscence; seeds without distinct tails.

sect. Pogonanthum - Scales incised; corolla salver-shaped; stamens 5-8, included, staminal filaments glabrous or hairy towards the base; capsule valves not twisting after dehiscence; seeds without distinct tails.

sect. Vireya - Scales sessile or sometimes stalked, lobed to deeply incised or sometimes entire; corolla campanulate, trumpet-like, salver-shaped, tubular or funnel-shaped; stamens $(5-) 10(-16)$, exserted to included, staminal filaments glabrous or hairy from the base; capsule valves twisting after dehiscence; seeds with a distinct tail at each end.

subsect. Euvireya - Scales sessile or stalked, scattered or dense, not of two obviously different size classes, lobed to deeply incised (or sometimes entire) and the centre not dark-coloured.

subsect. Malayovireya - Scales sessile, dense, of two obviously different size classes, lobed and the centre dark-coloured.

sect. Pseudovireya - Scales entire; corolla campanulate; stamens 10, exserted, staminal filaments glabrous proximally and distally and hairy in the middle region; capsule valves not twisting after dehiscence; seeds with a distinct tail at each end.

sect. Discovireya - Scales entire to undulate; corolla tubular-cylindric; stamens 10, exserted to included, staminal filaments glabrous or hairy from the base; capsule valves not twisting after dehiscence; seeds with a distinct tail at each end.

4. Rhododendron subsect. Euvireya contains species $26-74$ and 89-276 of Sleumer (1966), species 37-89 and 103-313 of Argent (2006), and the recently described $R$. dutartrei Danet and $R$. kogo Danet (Danet 2007). Subsection Malayovireya contains species 75-88 of Sleumer (1966) and species 90-102 of Argent (2006). Section Pseudovireya contains species 1-11 of Argent (2006). Section Discovireya contains species 1-25 of Sleumer (1966) and 12-36 of Argent (2006).

\section{KEY TO THE SECTIONS AND SUBSECTIONS OF SUBGENUS RHODODENDRON}

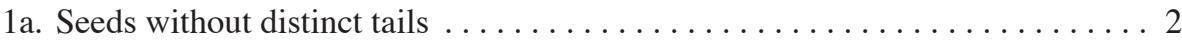

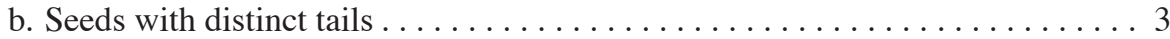

2a. Corolla campanulate to funnel-shaped or tubular; scales entire to crenulate ..... sect. Rhododendron

b. Corolla salver-shaped; scales incised $\ldots \ldots \ldots \ldots \ldots$ sect. Pogonanthum 
3a. Capsule valves twisting after dehiscence; scales variously incised or rarely entire

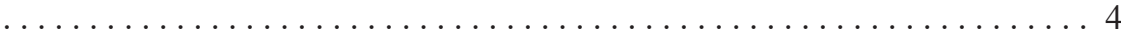

b. Capsule valves not twisting after dehiscence; scales entire to undulate . . . . . 5

4a. Scales sessile, dense, of two obviously different size classes, lobed, centre darkcoloured .................... sect. Vireya subsect. Malayovireya

b. Scales sessile or stalked, scattered or dense, not of two obviously different size classes, lobed to deeply incised (or sometimes entire), centre not dark-coloured $\ldots \ldots \ldots \ldots \ldots \ldots \ldots \ldots \ldots \ldots \ldots \ldots \ldots \ldots \ldots$ sect. Vireya subsect. Euvireya

5a. Corolla campanulate; staminal filaments glabrous proximally and distally and hairy in the middle region. . . . . . . . . . . . . . . . sect.

b. Corolla tubular-cylindric; staminal filaments glabrous or hairy from the base.... sect. Discovireya

\section{KEY TO THE INFORMAL GROUPS OF SUBSECTION EUVIREYA}

1a. Scales entire.................. subsect. Euvireya 'Siphonovireya'

b. Scales lobed to deeply incised . . . . . . . . . . . . . . . . . 2

2a. Scales deeply incised, stalked, each inserted on a distinct and permanent tubercle subsect. Euvireya 'Phaeovireya'

b. Scales shallowly or deeply incised, sessile or rarely stalked, rarely inserted on an

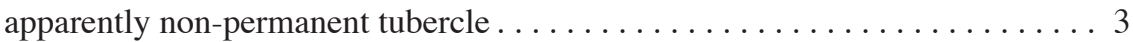

3a. Scales dense, usually overlapping . ......... subsect. Euvireya 'Albovireya'

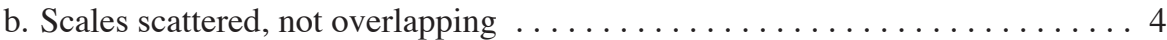

4a. Corolla trumpet-like or salver-shaped, tube narrow, lobes equalling 1/4 or less of the total corolla length and spreading \pm at right angles to the tube ............................ subsect. Euvireya 'Solenovireya'

b. Corolla campanulate or tubular or funnel-shaped, tube usually relatively broad, lobes equalling $1 / 4$ or more of the total corolla length and erect to spreading-ascending or rarely \pm at right angles to the tube.......... subsect. Euvireya 'Euvireya'

\section{ACKNOWLEDGEMENTS}

Kirsten Cowley is thanked by LAC for her willing cooperation in locating literature, printing documents and facilitating their transport during a period in which he was away from the herbarium, and David Jones is thanked for providing the courier service. JeF Veldkamp is acknowledged for his assistance with certain aspects of nomenclature.

\section{REFERENCES}

Argent, G. 2006. Rhododendrons of subgenus Vireya. Royal Horticultural Society, London.

Blume, C.L. 1826. Bijdragen tot de Flora van Nederlandsch Indië 15: 851-941. Lands Drukkerij, Batavia.

Brown, G. K., L. A. Craven, F. Udovicic \& P. Y. Ladiges. 2006a. Phylogeny of Rhododendron section Vireya (Ericaceae) based on two non-coding regions of cpDNA. Pl. Syst. Evol. 257: 57-93.

Brown, G.K., L.A. Craven, F. Udovicic \& P.Y. Ladiges. 2006b. Phylogenetic relationships of Rhododendron section Vireya (Ericaceae) inferred from the ITS nrDNA region. Austral. Syst. Bot. 19: $329-342$. 
Chamberlain, D.F., R. Hyam, G. Argent, G. Fairweather \& K.S. Walter. 1996. The genus Rhododendron - its classification and synonymy. Royal Botanic Garden, Edinburgh.

Clarke, C.B. 1882. Rhododendron subg. Vireya, Rhododendron subg. Pseudovireya. In: J.D. Hooker, Flora of British India 3: 462, 464. Reeve \& Co., Brook, near Ashford.

Copeland, H.F. 1929. Philippine Ericaeae, I: The species of Rhododendron. Philipp. J. Sci. 40: $133-179$.

Danet, F. 2007. Deux nouvelles espèces de Rhododendron section Siphonovireya (Ericaceae) de Nouvelle-Guinée. Adansonia sér. 3, 29: 105-111.

Goetsch, L.A., A.J. Eckert \& B.D. Hall. 2005. The molecular systematics of Rhododendron (Ericaceae): A phylogeny based upon RPB2 gene sequences. Syst. Bot. 30: 616-626.

Greuter, W., J. McNeill, F.R. Barrie, H.M. Burdet, V. Demoulin, T.S. Filgueiras, D. Nicolson, P.C. Silva, J.E. Skog, P. Trehane, J.N. Turland \& P.M. Hawksworth. 2000. International code of botanical nomenclature (Saint Louis Code) adopted by the sixteenth International Botanical Congress, St Louis, Missouri, July-August 1999. Koeltz, Konigstein (Regnum Vegetabile 138).

Hall, B.D., L.A. Craven \& L.A. Goetsch. 2006. The taxonomy of subsection Pseudovireya - two distinctly different taxa within subsection Pseudovireya and their relation to the rooting of section Vireya within subgenus Rhododendron. Rhododendron Sp. 1: 72, 91-97.

Hutchinson, J. 1930. Vaccinioides series. In: J.B. Stevenson, The species of Rhododendron: 817-826. Rhododendron Society, London.

Kurashige Y., J.-I. Etoh, T. Handa, K. Takayanai \& T. Yukawa. 2001. Sectional relationships in the genus Rhododendron (Ericaceae): evidence from matK and trnK intron sequences. Plant Syst. Evol. 228: 1-14.

Kurashige, Y., M. Mine, N. Kobayashi, T. Handa, K. Takatanagi \& T. Yukawa. 1998. Investigation of sectional relationships in the genus Rhododendron (Ericaceae) based on matK sequences. J. Jap. Bot. 73: 143-154.

Schlechter, R. 1917. Linnaeopsis. Bot. Jahrb. Syst. 55: 144-145.

Sleumer, H. 1949. Ein System der Gattung Rhododendron L. Bot. Jahrb. Syst. 74: 511-553.

Sleumer, H. 1958. Rhododendron subsect. Malayovireya. Blumea Suppl. 4: 48.

Sleumer, H. 1960. Florae Malesianae precursores XXIII: The genus Rhododendron in Malaysia. Reinwardtia 5: 45-231.

Sleumer, H. 1966. Rhododendron. Flora Malesiana, Ser. I, 6: 474-668. [Reprinted as 'An account of Rhododendron in Malesia' with an introduction and index.]

\section{APPENDIX 1}

Voucher details for the majority of species included in Fig. 1 are given in Goetsch et al. (2005). Details for the other species are: R. kawakamii, Goetsch 93; R. gracilentum, Goetsch 104; R. carringtoniae, Goetsch 105; R. javanicum, Goetsch 106; R. pauciflorum, Goetsch 107; R. euonymifolium, Goetsch 108 (all WTU); R. rubineiflorum, Craven \& Brown 10373; R. inundatum, Craven 10481; R. ruttenii, Craven 10436; $R$. alborugosum, Craven 10634; R. rhodopus, Brown, Craven, Juswara \& Ramadanil 129; R. zollingeri, Brown, Craven, Juswara \& Ramadanil 125; R. rarilepidotum, Craven 10636; R. fallacinum, Craven 10635; R. malayanum, Craven \& Brown 10371; $R$. ericoides, Craven \& Brown 10362; R. quadrasianum, Craven \& Brown 10379; $R$. citrinum, Binney s.n.; R. meliphagidum, Binney s.n.; R. adinophyllum, Binney s.n. (all CANB). 